\title{
Palatability and digestibility of horse diets containing increasing levels of citrus pulp
}

\section{Palatabilidad y digestibilidad de las dietas que contienen pulpa de cítricos para caballos}

\author{
Camilla G Moreira, ${ }^{1}$ M.Sc, Ives CS Bueno, ${ }^{1}$ Ph.D, Madalena L Menezes, ${ }^{1}$ M.Sc, \\ Thaís P Mota, ${ }^{1}$ Zoot, Aline D Souza, ${ }^{1}$ Zoot, Amanda F Tavares, ${ }^{1}$ Zoot, \\ Laise S Augusto, ${ }^{1}$ Zoot, Roberta A Brandi, ${ }^{1 *}$ Ph.D.
}

\begin{abstract}
${ }^{1}$ Departamento de Zootecnia, Faculdade de Zootecnia e Engenharia de Alimentos - FZEA/ USP, Pirassununga, SP. Brasil. Av. Duque de Caxias norte, 225. Campus USP, CEP: 13635-900. *Correspondence: robertabrandi@usp.br
\end{abstract}

Received: May 2014; Accepted: January 2015.

\begin{abstract}
Objective. To evaluate the impact of citrus pulp on the palatability and digestibility of horse diets and the physicochemical characteristics of the feces. Materials and methods. The diets were composed of $60 \%$ of the energy from the forage and $40 \%$ from the concentrate, with increasing levels of citrus pulp. Two different tests were performed. The first test assessed the palatability of concentrates. Using a randomized experimental design, 15 horses were observed for 10 days. The variables recorded were first action, first choice and intake ratio (IR). Five horses were arranged in $5 \times 5$ Latin Square design for the test assessing digestibility and fecal physicochemical characteristics. The apparent digestibility of the nutrients and the color, consistency, $\mathrm{pH}$ and buffering capacity (BC) of the feces were evaluated. Results. The addition of increasing levels of citrus pulp had an effect $(p \leq 0.001)$ on first action. A difference was also observed in first choice, and the addition of 0,7 or $14 \%$ of citrus pulp was preferred. A difference between treatments $(p \leq 0.001)$ was also observed for IR, and the control concentrate was consumed the most. The amount of citrus pulp included had no effect $(p>0.05)$ on the digestibility of nutrients, fecal consistency and color, and there was no effect $(p>0.05)$ on fecal $\mathrm{pH}$ and BC. Conclusions. Horses can identify the presence of citrus pulp in concentrates but prefer concentrates without added citrus pulp. Citrus pulp does not negatively affect the digestibility of concentrates or the physicochemical characteristics of the feces; thus, citrus pulp is a viable alternative ingredient in the formulation of horse diets.
\end{abstract}

Key words: Fecal pH, pectin, preference, super fiber (Source: $C A B$ ).

\section{RESUMEN}

Objetivo. Evaluar la inclusión de pulpa de cítricos en la dieta de los caballos a través de la evaluación de la de palatabilidad, digestibilidad y características fisicoquímicas de las heces. Materiales y métodos. El valor energético de las dietas fue aportado en el $60 \%$ por la energía del forraje y en el $40 \%$ a partir del concentrado con niveles crecientes de pulpa de cítricos. En la primera prueba se evaluó la palatabilidad de los concentrados. Se utilizó un diseño experimental aleatório. Se observaron 
15 caballos durante 10 días. Las variables registradas fueron la primera acción, la primera opción y la relación de la ingesta (IR). Cinco caballos fueron dispuestos en un diseño cuadrado latino $5 \times 5$ para la evaluación de la digestibilidad y las características fisicoquímicas fecales. La digestibilidad de los nutrientes y el color, la consistencia, el pH, y se evaluó la capacidad de tamponamiento (CT) de las heces. Resultados. El nível de inclusión de pulpa de cítricos tuvo un efecto $(p<0.001)$ en la primera acción. Una diferencia también se observó en primera elección. Una diferencia $(p<0.001)$ entre los tratamientos también se observó para IR. El nível de inclusión de pulpa de cítricos no efectó $(p>0.05)$ la digestibilidad, consistencia fecal y el color de las heces, $\mathrm{pH}$ fecal y CT de las heces. Conclusiones. Los caballos pueden identificar la presencia de pulpa de cítricos en los concentrados, pero prefieren concentrados sin pulpa de cítricos. La pulpa de cítricos no afecta la digestibilidad de los nutrimentos en el concentrado, ni las características fisicoquímicas de las heces; la pulpa de cítricos es un ingrediente alternativo viable en la formulación de dietas para caballos.

Palabras clave: Pectina, pH fecal, preferencia, super fibra (Fuente: $C A B$ ).

\section{INTRODUCTION}

The horses can use large quantities of forage to meet their nutritional requirements (1). However, diets with a high percentage of grains are used to maximize productivity (2). Currently, researchers are searching for alternative ingredients that can replace traditional ingredients such as corn, soybean meal and wheat bran for use the alternative ingredients, easily fermentable fibers, or "super fibers", such as citrus pulp, seem especially promising (3).

However, only a few studies have been published regarding the use of citrus pulp in horse feed (4-7). Ott et al (4) investigated the acceptability and digestibility of diets with increasing levels of citrus pulp $(0,15$ and $30 \%$ ) and observed that diets with $30 \%$ citrus pulp were rejected by horses. Nevertheless no difference was observed in the digestibility of the nutrients. Manzano et al (5) observed an increase in the digestibility of dry matter and crude protein with the addition of citrus pulp; these authors using no more than $15 \%$ citrus pulp to prevent a decrease in palatability.

Another important factor to determine the digestibility of horse diets is the physicochemical characteristics of the feces, as:

Feces parameters (8) such as color (9), consistency (10), $\mathrm{pH}(8)$ and buffering capacity (BC) (11) are important to evaluate the gastrointestinal tract health (10).

The aim of this study was to evaluate the effect of increasing levels of citrus pulp in concentrate on the palatability and apparent digestibility of horse diets, as well as the physicochemical characteristics of the feces.

\section{INTRODUCCIÓN}

Los caballos pueden usar grandes cantidades de forraje para satisfacer sus requerimientos nutricionales (1). Sin embrago, las dietas con altos porcentajes de granos se utilizan para maximizar la productividad (2). En la actualidad, los investigadores buscan ingredientes alternativos que puedan reemplazar a los ingredientes tradicionales como el maíz, la harina de soya y el salvado de trigo por el uso de ingredientes alternativos, las fibras de fácil fermentación, o "superfibras", como la pulpa de cítricos, parecen ser especialmente prometedoras (3).

Sin embargo, sólo se han publicado unos pocos estudios relativos al uso de pulpa de cítricos en los alimentos para caballos (4-7). Ott et al (4) investigó la aceptabilidad y la digestibilidad de las dietas con niveles cada vez mayores de pulpa de cítricos $(0,15$ y $30 \%)$ y observó que los caballos rechazaron las dietas con un $30 \%$ de pulpa de cítricos. Sin embrago, no observó diferencia alguna en la digestibilidad de la materia seca y la proteína cruda al añadir pulpa de cítricos; éstos autores no usaron un porcentaje mayor al $15 \%$ de pulpa de cítricos para evitar una disminución en la palatabilidad.

Otro factor importante para determinar la digestibilidad de las dietas para caballos son las características fisicoquímicas de las heces, tales como:

Algunos parámetros de las heces (8) como el color (9), la consistencia (10), el pH (8) y la capacidad tampón (CT) (11) son importantes para evaluar la salud del tracto gastrointestinal (10).

El objetivo de este estudio fue el de evaluar el efecto de niveles cada vez mayores de pulpa de cítricos en el concentrado sobre la digestibilidad y palatabilidad de los alimentos para caballos, como también sobre las características fisicoquímicas de las heces. 


\section{MATERIALS AND METHODS}

Study site. This study was performed in the Equine Production section of the Pirassununga Administrative Campus of Animal Science and Food Engineering School, University of São Paulo.

Two experiments were conducted: a palatability test (test 1 ) and a test of apparent digestibility and physicochemical characteristics of feces (test 2).

Animals and experimental design. Fifteen horses, 10 years old, and $400 \mathrm{~kg}$ body weight, were used in the study. The adaptation period lasted five days and the experimental period lasted 10 days; protocol was performed once a day totalizing 150 observations. The animals were observed by instantaneous focal sampling for three consecutive minutes, and an ethogram to organize the dates. It was tested concentrates with $0,7,14,21$ or $28 \%$ citrus pulp (Table 1 ).

Table 1. Percentage composition of the experimental concentrates with increasing levels of citrus pulp added to the diet.

\begin{tabular}{cccccc}
\hline \multirow{2}{*}{ Ingredients } & \multicolumn{6}{c}{ Level of citrus pulp added to the diet } \\
& $\mathbf{0 \%}$ & $\mathbf{7 \%}$ & $\mathbf{1 4 \%}$ & $\mathbf{2 1 \%}$ & $\mathbf{2 8 \%}$ \\
\hline Ground corn & 60.43 & 60.32 & 59.00 & 58.0 & 55.92 \\
Soybean meal & 3.90 & 6.20 & 5.73 & 7.95 & 9.45 \\
Wheat bran & 30.00 & 21.00 & 16.00 & 7.93 & 1.78 \\
Citrus pulp & 0.00 & 7.00 & 14.00 & 21.0 & 28.00 \\
Premix* & 0.67 & 0.67 & 0.67 & 0.67 & 0.67 \\
Lime & 2.86 & 2.30 & 1.82 & 1.33 & 0.81 \\
Dicalcium phosphate & 1.27 & 1.63 & 1.90 & 2.25 & 2.50 \\
Salt & 0.88 & 0.88 & 0.88 & 0.88 & 0.88 \\
\hline
\end{tabular}

* Guaranteed Analysis: Linoleic acid: $3.630 \mathrm{mg}$; Oleic Acid: $3 \mathrm{mg}$; Calcium (Min): $150 \mathrm{~g}$; Calcium (max.): $170 \mathrm{mg}$; Phosphorus: $80 \mathrm{~g}$, Sodium $121 \mathrm{~g}$, Potassium: $10 \mathrm{~g}$; Sulfur: $4.954 \mathrm{mg}$; Cobalt: $30 \mathrm{mg}$; Tyrosine: $34 \mathrm{mg}$, Copper: $1.400 \mathrm{mg}$; Iodine: $200 \mathrm{mg}$; Chrome: 12 $\mathrm{mg}$; Lysine: $4.000 \mathrm{mg}$; Magnesium: $7.225 \mathrm{mg}$; Manganese: $1.400 \mathrm{mg}$; Phosphatidylcholine: $1,000 \mathrm{mg}$; Methionine: $14 \mathrm{mg}$, Selenium: $27 \mathrm{mg}$, Iron: $2000 \mathrm{mg}$, Zinc: $3.500 \mathrm{mg}$, Vitamin A: $85,000 \mathrm{KIU} / \mathrm{kg}$, Vitamin C: 200 mg, Vitamin D: 8,500 KIU/kg, Vitamin E: 200 mg; Saccharomyces cerevisiae: $0.01500 \times 10^{7} \mathrm{CFU}$.

Before starting the trial, the animals received 1 $\mathrm{kg}$ of concentrate (different from concentrates to be tested) in stall one hour before the test and were then led individually to the arena to conduce the trial. The troughs containing $200 \mathrm{~g}$ of each concentrate were arranged in five equidistant points, and the treatments and animals were randomized each day.

The preference test was used to assess the palatability of the concentrates (12). The first action (1 - sniffed, 2 - ate), first choice (first concentrate actually consumed) and intake ratio (amount of each concentrate ingested) were evaluated.

\section{MATERIALES Y MÉTODOS}

Lugar del estudio. Este estudio se realizó en la sección de Producción Equina del Campus Administrativo Pirassunga de la Facultad de Ciencias Animales e Ingeniería de Alimentos, Universidad de São Paulo.

Se realizaron dos experimentos: una prueba de palatabilidad (prueba 1) y una prueba de la digestibilidad aparente y las características fisicoquímicas de las heces (prueba 2).

Animales y diseño experimental. En este estudio se utilizaron quince caballos, de 10 años de edad y con un peso corporal de $400 \mathrm{~kg}$. El periodo de adaptación duró cinco días y el periodo experimental duró 10 días; el protocolo se llevo a cabo una vez por día para un total de 150 observaciones. Los animales fueron observados mediante un muestreo focal instantáneo durante tres minutos consecutivos, utilizando un etograma para organizar las fechas.

Antes de iniciar el estudio, los animales recibieron $1 \mathrm{~kg}$ de concentrado (distinto a los concentrados que serían sujetos a prueba) en una cuadra una hora antes de realizar la prueba y luego fueron llevados individualmente al estadio para realizar el estudio. Los comederos, cada uno con $200 \mathrm{~g}$ de concentrado, se organizaron en cinco puntos equidistantes, y los tratamientos y animales fueron aleatorizados diariamente.

La prueba de preferencia se utilizó para evaluar la palatabilidad de los concentrados (12). Se evaluaron la primera acción (1-olisqueó, 2-comió), la primera elección (primer concentrado consumido efectivamente) y la tasa de ingesta (cantidad de concentrado ingerida).

Las sobras fueron retiradas y pesadas, y la tasa de ingesta (TI) se calculó utilizando la siguiente ecuación:

$\mathrm{TI}=$ concentrado ( $\%$ de pulpa de cítricos)/ (ingesta de $0 \%$ de concentrado + ingesta de $7 \%$ de concentrado + ingesta de $14 \%$ de concentrado + ingesta de $21 \%$ de concentrado + ingesta de $28 \%$ de concentrado).

Análisis estadístico. El diseño experimental fue de parcela dividida. Se utilizó una prueba chi cuadrado de bondad de ajuste para evaluar la primera elección y la primera acción, bajo la hipótesis nula de que todos los tratamientos ocurrirían con la misma probabilidad.

Un modelo mixto lineal con esquema factorial de $5 \times 10$ se utilizó para analizar la TI, teniendo en 
The leftovers were removed and weighed, and the intake ratio (IR) was calculated using the equation below:

IR = concentrate ( $\%$ citrus pulp) / (intake of $0 \%$ concentrate + intake of $7 \%$ concentrate + intake of $14 \%$ concentrate + intake of $21 \%$ concentrate + intake of $28 \%$ concentrate).

Statistical analysis. The experimental design was a split pot. A chi-square goodness of fit test was used to evaluate the first choice and first action, under the null hypothesis that all treatments would occur with equal probability.

A linear mixed model with a $5 \times 10$ factorial scheme was used to analyze the IR, taking into consideration the fixed effects of the treatment and the day, as well as the random effect of the animal, in addition to the effect of the residue. In the case of a significant interaction, Student's t test was used to assess each treatment within each evaluation day. All analyses were performed using the Statistical Analysis System software, version 9.1.3. (13).

Animals and experimental design. Were used five nonpregnant mares, Brasileiro de Hipismo breed, weighing $406.6 \pm 76.86 \mathrm{~kg}$ and aging six years were housed in individual stalls and arranged in 5x5 Latin Square design. The experimental period included seven days of adaptation followed by three days of data collection and analysis.

The experimental diets were formulated to meet the maintenance requirements for horses, as recommended by the National Research Council, 2007 (14). The diet were composed by $60 \%$ of the energy coming of forage (Coast Cross hay) and $40 \%$ came from concentrate with increasing levels of citrus pulp $(0,7,14,21$ and 28\%), (Table 1 and Table 2).

To evaluate the physicochemical characteristics of the feces, the samples were collected for three days in plastic bags. Subsequently, the $\mathrm{pH}$ was measured using a bench $\mathrm{pH}$ meter, and the BC was measured as described in Zeyner et al (11).

The consistency of the feces was evaluated as described by Berg et al (9), and the feces color was evaluated as described by Godoi et al (8).

Laboratory methods. A composite sample from each animal was obtained at the end of the experiment and sent to the Bromatology laboratory at the FZEA/USP. The dry matter (DM), mineral matter (MM), ether extract (EE) and cuenta los efectos fijos del tratamiento y del día, además del efecto aleatorio del animal y el efecto del residuo. En caso de haber una interacción significativa, se utilizó la prueba t de Student para evaluar cada tratamiento dentro de cada día de evaluación. Todos los análisis de llevaron a cabo utilizando el software Statistical Analysis System, versión 9.1 .3 (13).

Animales y diseño experimental. Se utilizaron cinco yeguas no embarazadas, de raza Brasileiro de Hipismo, con un peso de 406.6士76.86 kg y de seis años de edad, las cuales fueron alojadas en cuadras independientes dispuestas en diseño Cuadrado Latino de $5 \times 5$. El periodo experimental incluyó siete días de adaptación seguidos de tres días de recolección de datos y análisis.

Las dietas experimentales se formularon para cumplir con los requisitos de manutención de caballos, conforme a las recomendaciones del Concejo de Investigación Nacional, 2007 (14). Las dietas estuvieron compuestas de un $60 \%$ de la energía proveniente de forraje (heno Cross Coast) y el $40 \%$ restante de concentrado con niveles cada vez mayores de pulpa de cítricos $(0,7,14,21$ y 28\%), (Tabla 1 y Tabla 2).

Para evaluar las características fisicoquímicas de las heces, se tomaron muestras en bolsas de plástico durante tres días. Posteriormente, se midió el $\mathrm{pH}$ utilizando un medidor de $\mathrm{pH}$ de banco, y la CT se midió conforme a lo descrito por Zeyner et al (11).

La consistencia de las heces fue evaluada conforme a los descrito por Berg et al (9), y el color de las heces se midió conforme a lo descrito por Godoi et al (8).

Métodos de laboratorio. Se obtuvo una muestra compuesta de cada animal al final del experimento y se envió al laboratorio de Bromatología del FZE/USP. Los contenidos de materia seca (MS), materia mineral $(M M)$, extracto de éter (EE) y proteína cruda (PC) de los concentrados, el heno y las heces fueron determinados de acuerdo a los procedimientos de la Asociación de Química Analítica Oficial (15). Los contenidos de fibra detergente acida (FDA), fibra detergente neutra (FDN), celulosa (CEL) y hemicelulosa (HEM) fueron analizados conforme a lo descrito por Van Soest et al (16). Se determinó la energía bruta (EB) utilizando una bomba calorimétrica.

Determinamos además los coeficientes de digestibilidad de MS, MO PC, EE, FDA, CEL, HEM y EB. 
Table 2. Chemical composition of concentrates and experimental diets with increasing levels of citrus pulp added to the diet.

\begin{tabular}{|c|c|c|c|c|c|c|c|c|}
\hline \multirow{2}{*}{ Nutrient } & \multirow{2}{*}{ Hay 1} & \multirow{2}{*}{ Hay 2} & \multirow{2}{*}{ Hay 3} & \multicolumn{5}{|c|}{ Level of citrus pulp added to the diet $(\%)$} \\
\hline & & & & $\mathbf{0}$ & 7 & 14 & 21 & 28 \\
\hline Dry Matter & 85.29 & 85.67 & 83.41 & 88.48 & 88.6 & 87.92 & 88.29 & 88.28 \\
\hline Organic Matter & 94.51 & 92.99 & 93.58 & 93.22 & 92.32 & 93.79 & 93.9 & 93.22 \\
\hline Mineral Matter & 5.49 & 7.01 & 6.42 & 6.78 & 7.68 & 6.21 & 6.1 & 6.78 \\
\hline Crude Protein & 13.11 & 12.53 & 12.8 & 13.92 & 12.52 & 13.74 & 13.9 & 13.96 \\
\hline Crude Fiber & 31.1 & 31.82 & 30.73 & 5.78 & 6.54 & 5.86 & 5.95 & 6.07 \\
\hline Ether Extract & 0.56 & 0.62 & 0.65 & 3.87 & 3.02 & 3.29 & 3.1 & 3.26 \\
\hline Nitrogen-free extract & 49.74 & 48.02 & 49.4 & 69.65 & 70.24 & 70.9 & 70.95 & 69.93 \\
\hline Acid detergent fiber & 39.11 & 35.55 & 35.35 & 5.25 & 5.74 & 8.98 & 7.07 & 7.63 \\
\hline Neutral detergent fiber & 83.69 & 68.77 & 69.65 & 22.29 & 26.06 & 21.46 & 26.92 & 21.77 \\
\hline Hemicellulose & 44.58 & 33.22 & 34.3 & 17.04 & 20.32 & 12.48 & 19.85 & 14.14 \\
\hline Calcium & - & - & - & 1.63 & 1.54 & 1.4 & 1.49 & 1.39 \\
\hline Phosphorus & - & - & - & 0.57 & 0.51 & 0.53 & 0.54 & 0.56 \\
\hline Starch & - & - & - & 39.09 & 35.5 & 34.61 & 36.58 & 32.29 \\
\hline \multirow[t]{3}{*}{ Gross energy $(\mathrm{Kcal} / \mathrm{kg})$} & 4136.00 & 3954.00 & 3957.00 & 3684.00 & 3706.00 & 3771.00 & 3809.00 & 3826.00 \\
\hline & \multicolumn{8}{|c|}{ Chemical composition of the experimental diets ( $60: 40$ forage:concentrate ratio) } \\
\hline & $\mathbf{0}$ & & 7 & 14 & & 21 & & 8 \\
\hline Dry Matter & 86.27 & & 86.31 & 86.04 & & 86.19 & & 19 \\
\hline Organic Matter & 93.50 & & 93.14 & 93.73 & & 93.77 & & 50 \\
\hline Mineral Matter & 6.50 & & 6.86 & 6.27 & & 6.23 & & 50 \\
\hline Crude Protein & 13.25 & & 12.69 & 13.18 & & 13.25 & & 27 \\
\hline Crude Fiber & 21.04 & & 21.35 & 21.08 & & 21.11 & & 16 \\
\hline Ether Extract & 1.91 & & 1.57 & 1.68 & & 1.61 & & 67 \\
\hline Nitrogen-free extract & 57.29 & & 57.53 & 57.59 & & 57.81 & & 40 \\
\hline Acid detergent fiber & 24.10 & & 24.30 & 25.59 & & 24.83 & & 05 \\
\hline Neutral detergent fiber & 53.34 & & 54.85 & 53.01 & & 55.19 & & 13 \\
\hline Hemicellulose & 29.24 & & 30.55 & 27.41 & & 30.36 & & .08 \\
\hline Gross energy (Kcal/kg) & 3883.00 & & 3891.80 & 3917.80 & & 3933.00 & 393 & 9.80 \\
\hline
\end{tabular}

crude protein (CP) contents of the concentrates, hay and feces were determined according to the procedures described by the Association of Official Analytical Chemistry (15). The acid detergent fiber (ADF), neutral detergent fiber (NDF), cellulose (CEL) and hemicellulose (HEM) contents were analyzed as described by Van Soest et al (16). The gross energy (GE) was determined using a bomb calorimeter.

We further determined the digestibility coefficients of DM, OM, CP, EE, NDF, ADF, CEL, HEM and GE.

Statistical analysis. To evaluate the digestibility, we used the $5 \times 5$ Latin Square design using five animals fed with five diets with increasing levels of citrus pulp, repeated in five consecutive periods. The quantitative parameters were analyzed according to the statistical model:

$Y_{i j k}=\mu+A_{i}+T_{j}+P_{k}+\varepsilon_{i j k}$

Where,

$Y_{i j k}$ represents the dependent variable

$\mu$, the overall mean
Análisis estadístico. Para evaluar la digestibilidad utilizamos el diseño Cuadrado Latino de $5 \times 5$ utilizando cinco animales alimentados con cinco dietas con niveles cada vez mayores de pulpa de cítrico, repitiéndolo en cinco periodos consecutivos. Los parámetros cuantitativos fueron analizados de acuerdo al siguiente modelo estadístico:

$Y_{i j k}=\mu+A_{i}+T_{j}+P_{k}+\varepsilon_{i j k}$

En donde,

$\mathrm{Y}_{\mathrm{ijk}}$, representa la variable dependiente

$\mu$, la media global

$A_{i}$, el efecto del animal ( $i=1$ a 5$)$

$\mathrm{T}_{\mathrm{j}}$, el efecto del tratamiento ( $\mathrm{j}=1$ a 5 )

$\mathrm{P}_{\mathrm{k}^{\prime}}$ el efecto del periodo $(\mathrm{k}=1$ a 5$) \mathrm{y}$

$\varepsilon_{\mathrm{ijk}}$ el error residual.

Se utilizó la función PROC GLM del paquete estadístico del SAS para Windows (13) para el análisis estadístico. Las medias se compararon utilizando la prueba de Turkey con un nivel de probabilidad del $5 \%$. 
$A_{i}$, the effect of the animal ( $i=1$ to 5 )

$T_{j}$, the effect of the treatment ( $j=1$ to 5$)$

$\mathrm{P}_{\mathrm{k}}$, the effect of the period ( $\mathrm{k}=1$ to 5 ) and

$\varepsilon_{\mathrm{ijk}}$, the residual error.

The PROC GLM function of the SAS statistical package for Windows (13) was used for statistical analysis. The means were compared by Tukey's test with a probability level of $5 \%$.

The consistency and color of the feces were assessed using the chi-square goodness of fit test. The $\mathrm{BC}$ and fecal $\mathrm{pH}$ were assessed using the mixed linear model function of the SAS (13) program.

\section{RESULTS}

Palatability. There was a difference in first action $(p \leq 0.001), 66.91 \%$ of the animals sniffed the concentrates upon initial exposure to them, while $33.09 \%$ of the animals ate the concentrates. There was a difference $(p<0.001)$ between treatments for the first choice variable, and treatment with 0,7 and $14 \%$ citrus pulp were preferred (Table 3 ). There was a difference $(p \leq 0.001)$ in IRs, as the control treatment $(0 \%)$ was consumed the most, followed by treatments with 7, 14, 21 and $28 \%$ citrus pulp (Table 3 ).

Apparent digestibility of the diets and physicochemical characteristics of the feces. The addition of citrus pulp had no effect ( $p>0.05$ ) over the digestibility coefficients of DM, CP, OM, EE, GE, CEL, HEM, NDF or ADF (Table 4).

Treatment with citrus pulp had no effect ( $p>0.05$ ) on fecal consistency or color. The color of the feces remained greenish, and the consistency was classified as normal (score of 3 ). Adding citrus pulp had no effect $(p>0.05)$ on $B C$ or fecal $\mathrm{pH}$. The mean values observed for $\mathrm{BC}$ at $\mathrm{pH} 5$, $\mathrm{BC}$ at $\mathrm{pH} 6$ and $\mathrm{pH}$ are shown in table 5 .

Table 3. First choice and intake ratio of concentrates with increasing levels of citrus pulp added to the diet.

\begin{tabular}{ccc}
\hline Treatment & First choice (\%) & Intake Ratio \\
\hline $0 \%$ & 21.46 & $0.3137^{\mathrm{a}}$ \\
$7 \%$ & 28.78 & $0.2366^{\mathrm{b}}$ \\
$14 \%$ & 28.06 & $0.1913^{\mathrm{bc}}$ \\
$21 \%$ & 11.51 & $0.1521^{\mathrm{cd}}$ \\
$28 \%$ & 7.19 & $0.1087^{\mathrm{d}}$ \\
\hline
\end{tabular}

Lowercase letters indicate significantly different pairs, as determined by Student's t test $(p<0.001)$.
Se evaluaron la consistencia y el color de las heces utilizando la prueba chi cuadrado de bondad de ajuste. La CT y el PH fecal fueron evaluados utilizando la función de modelo lineal mixto del programa SAS (13).

\section{RESULTADOS}

Palatabilidad. Se encontró una diferencia en la primera acción ( $\mathrm{p} \leq 0.001), 66.91 \%$ de los animales olisquearon los concentrados al ser expuestos a ellos por primera vez, mientras que $33.09 \%$ de los animales comieron los concentrados. Se encontró una diferencia $(p \leq 0.001)$ entre los tratamientos para la variable de primera elección y se prefirieron los tratamientos con 0,7 y $14 \%$ de pulpa de cítricos (Tabla 3). Hubo una diferencia $(p \leq 0.001)$ en las TI, ya que el tratamiento de control $(0 \%)$ fue el más consumido, seguido por los tratamientos con contenido de pulpa de cítricos de 7, 14, 21 y $28 \%$ (Tabla 3).

Digestibilidad aparente de las dietas y características fisicoquímicas de las heces. El añadir pulpa de cítricos no tuvo efecto alguno $(p>0.05)$ en los coeficientes de digestibilidad de MS, PC, OM, EE, EB, CEL, HEM, FDN o FDA (Tabla 4).

El tratamiento con pulpa de cítricos no tuvo efecto alguno ( $p>0.05)$ en la consistencia o el color fecal. Las heces permanecieron de un color verdoso, y la consistencia se clasificó como normal (puntaje de 3 ). El añadir pulpa de cítricos no tuvo efecto $(p>0.05)$ en la CT o en el $\mathrm{pH}$ fecal. Los valores medios de CT en un $\mathrm{pH}$ de 5, CT en un $\mathrm{pH}$ de 6 y de $\mathrm{pH}$ se relacionan en la tabla 5 .

Table 4. Digestibility coefficients of the nutrients of diets with increasing levels of citrus pulp added to the diet.

\begin{tabular}{|c|c|c|c|c|c|c|c|}
\hline \multirow{2}{*}{ Nutrient } & \multicolumn{5}{|c|}{ Levels of added citrus pulp (\%) } & \multirow{2}{*}{$\mathrm{CV}^{*}$} & \multirow{2}{*}{ Mean } \\
\hline & 0 & 7 & 14 & 21 & 28 & & \\
\hline Dry matter ${ }^{1}$ & 48.74 & 49.24 & 49.14 & 49.68 & 47.65 & 5.83 & 48.89 \\
\hline Organic matter ${ }^{1}$ & 49.99 & 50.71 & 50.74 & 51.34 & 49.47 & 5.45 & 50.45 \\
\hline Crude protein ${ }^{1}$ & 60.27 & 58.98 & 60.75 & 59.53 & 60.22 & 4.59 & 59.95 \\
\hline Ether extract ${ }^{1}$ & 30.92 & 28.61 & 31.80 & 24.45 & 35.57 & 23.01 & 31.10 \\
\hline Neutral detergent fiber ${ }^{1}$ & 38.58 & 39.59 & 39.01 & 43.78 & 41.43 & 9.47 & 40.14 \\
\hline Acid detergent fiber ${ }^{1}$ & 24.98 & 30.40 & 31.02 & 39.50 & 32.76 & 18.69 & 32.15 \\
\hline Cellulose $^{1}$ & 27.16 & 30.94 & 32.80 & 40.31 & 35.27 & 17.54 & +32.95 \\
\hline Hemicellulose ${ }^{1}$ & 49.06 & 51.34 & 49.16 & 52.58 & 50.31 & 8.42 & 50.06 \\
\hline Gross energy $^{1}$ & 45.38 & 45.43 & 46.44 & 47.43 & 46.07 & 7.60 & 46.15 \\
\hline
\end{tabular}


Table 5. Buffering capacity and $\mathrm{pH}$ of feces from horses fed on diets with increasing levels of citrus pulp.

\begin{tabular}{cccc}
\hline Treatment & pH & $\begin{array}{c}\text { BC at pH 5 } \\
(\mathbf{m m o l} / \mathbf{l})\end{array}$ & $\begin{array}{c}\text { BC at pH 6 } \\
(\mathbf{m m o l} / \mathbf{L})\end{array}$ \\
\hline $0 \%$ & 6.62 & 15.83 & 5.27 \\
$7 \%$ & 6.69 & 16.92 & 5.54 \\
$14 \%$ & 6.64 & 16.94 & 5.37 \\
$21 \%$ & 6.51 & 15.24 & 3.71 \\
$28 \%$ & 6.67 & 17.79 & 5.67 \\
Means & 6.62 & 16.53 & 5.13 \\
\hline
\end{tabular}

\section{DISCUSSION}

Palatability. The first action performed by the animals upon to the initial exposure to the concentrates was sniffing (66.91\%), which demonstrates that horses can select the preferred concentrate through smell (17).

This selection ability was reiterated by observation of the first choice, which demonstrated that lower levels of citrus pulp (0,7 and 14\%) were preferred (Table 3 ). The concentrates containing $21 \%$ and $28 \%$ citrus pulp were chosen less frequently, most likely because citrus scents are not preferred by horses (18).

In an investigation of the acceptability and digestibility of diets with increasing levels of citrus pulp (0,15 and 30\%), Ott et al (4) observed that six out of eight horses refused a diet containing $30 \%$ citrus pulp. It was not observed effect when $28 \%$ citrus pulp was added to the concentrate in this trial.

In contrast to our results, Tribucci et al (18) found no effect of different levels of citrus pulp on the first choice when studying the palatability of diets with increasing levels of citrus pulp (7, 14,21 and $28 \%$ ) in horse diets. However, they did observe an effect on the first action. The methodology used in these studies may have influenced the results, as Tribucci et al (18) used continuous troughs in a stall, while our study used separate troughs in a round pen (open area). In addition, the authors of the previous study noted a strong citrus pulp odor, which we did not observe in this study.

Assis et al (19) reported that the palatability and composition of citrus pulp can be altered by factors such as: fruit varieties, the presence of seeds, whether essential oils are removed and the processes that the fruit and fruit residues were subjected to. This variation in the composition of citrus pulp may change the taste of the final product, and could therefore

\section{DISCUSIÓN}

Palatabilidad. La primera acción realizada por los animales al estar expuestos por primera vez a los concentrados fue olisquear $(66.91 \%)$, por lo cual se demuestra que los caballos pueden seleccionar el concentrado de su preferencia por medio del olfato (17).

Dicha capacidad de selección se reiteró por la observación de la primera elección, que demostró que se prefirieron los niveles más bajos de pulpa de cítricos (Tabla 3). Los concentrados con contenido de pulpa de cítricos de $21 \%$ y $28 \%$ fueron elegidos con menor frecuencia, probablemente porque los caballos no muestran una preferencia por los aromas cítricos (18).

En una investigación sobre la aceptabilidad y digestibilidad de dietas con niveles cada vez más altos de pulpa de cítricos $(0,15$ y $30 \%)$, Ott et al (4) observó que seis de cada ocho caballos rechazaron una dieta con un contenido de pulpa de cítricos del $30 \%$. Este efecto no se observó en este estudio al agregarle un $28 \%$ de pulpa de cítricos al concentrado.

A diferencia de nuestros resultados, Tribucci et al (18) no encontró ningún efecto en la primera elección causado por los distintos niveles de pulpa de cítricos al estudiar la palatabilidad de las dietas con cantidades cada vez mayores de pulpa de cítricos $(7,14,21$ y $28 \%)$ en las dietas de los caballos. Sin embrago, sí observaron un efecto en la primera acción. La metodología utilizada en estos estudios puede haber influenciado los resultados, ya que Tribucci et al (18) utilizó comederos continuos en una cuadra, mientras que en nuestro estudio se utilizaron comederos separados en un corral redondo (espacio abierto). Además, los autores del estudio anterior notaron un olor fuerte en la pulpa de cítricos, cosa que nosotros no observamos en este estudio.

Assis et al (19) reportó que la palatabilidad y la composición de la pulpa de cítricos pueden verse alteradas por factores como: la variedad de las frutas, la presencia de semillas y si los aceites esenciales fueron eliminados en los procesos a los que se sometieron las frutas y los residuos de las frutas. Esta variación en la composición de la pulpa de cítricos puede cambiar el sabor del producto final, por lo cual podría justificar las disparidades entre los estudios sobre esta materia.

Para reforzar la clara capacidad de selección de los caballos, observamos una TI mayor en concentrados con niveles menores de pulpa de cítricos (Tabla 3 ) y además los animales prefirieron el concentrado de control. 
account for the disparities between studies of this subject.

Reinforcing the distinct selection capacity of horses, we observed a higher IR for concentrates with lower levels of citrus pulp (Table 3), and the control concentrate was preferred by animals.

Considering only the IR, the concentrate containing $0 \%$ citrus pulp was the favorite, with an $I R=0.3137$ (the reference value for preference was IR>0.25). This reinforces the preference for this level $(0 \%)$ of citrus pulp in the concentrate.

Manzano et al (5) observed different results in their study of growing fillies when three levels of citrus pulp $(0,7.5$ and $15 \%)$ were added to the diet. The diet containing $15 \%$ citrus pulp was consumed more by the fillies. The animals in our study received experimental concentrates only during the evaluation, whereas in the protocol developed by Manzano et al (5), the animals received hay and the test concentrates.

The use of different tests to assess palatability and acceptability greatly influences experimental results. Ott et al (4) and Manzano et al (5) concluded that horses had a preference for certain diets by assessing intake and leftovers, whereas Müller and Udén (20) used the first choice test. In these studies, the duration of testing and the form of assessment were the primary variables. Our study analyzed multiple factors to explain preference; thus, it is difficult to compare our results with the literature. To better understand preference and feeding behavior, it is necessary to standardize the tests used in these studies.

Apparent digestibility of the diets and physicochemical characteristics of the feces. We observed different values for the nutrient digestibility coefficients (Table 4) compared to other studies (5-7), which may have been affected by factors such as: the forage:concentrate ratio, the composition of the diet ingredients and the quantity of food provided.

The total amount of DM provided per animal in this experiment was $2 \%$ of body weight, including at least $1 \%$ of the body weight of the animal as forage (Coast Cross hay), as recommended by the NRC (14). The forage: concentrate ratio was $60: 40$, based on the energy supply, representing a 75:25 DM ratio. Miraglia et al (6) analyzed the digestibility of different forage:concentrate ratios and observed that, as the percentage of concentrate increased, the apparent digestibility
Considerando únicamente la TI, el concentrado con un contenido de pulpa de cítricos de $0 \%$ fue el favorito, con una $\mathrm{TI}=0.3137$ (el valor de referencia para la preferencia fue de TI>0.259). Lo anterior refuerza la preferencia por este nivel (0\%) de pulpa de cítricos en el concentrado.

Manzano et al (5) observó resultados distintos en su estudio de potras en crecimiento cuando se agregaron tres niveles de pulpa de cítricos $(0,7.5$ y $15 \%$ ) a la dieta. La dieta con un contenido de pulpa de cítricos de $15 \%$ fue la más consumida por las potras. Los animales de nuestro estudio recibieron únicamente concentrados experimentales durante la evaluación, mientras que en el protocolo desarrollado por Manzano et al (5) los animales recibieron heno y los concentrados de prueba.

El empleo de distintas pruebas para evaluar la palatabilidad y la aceptabilidad influye significativamente en los resultados experimentales. Ott et al (4) y Manzano et al (5) llegaron a la conclusión de que los caballos prefirieron ciertas dietas al evaluar la ingesta y las sobras, mientras que Müller y Udén (20) utilizaron la prueba de primera elección. En estos estudios, la duración de las pruebas y la forma de evaluación fueron las principales variables. Nuestro estudio analizó múltiples factores para explicar la preferencia; por lo tanto, es difícil comparar nuestros resultados con la literatura. Es necesario estandarizar las pruebas utilizadas en estos estudios para entender mejor el comportamiento alimentario.

\section{Digestibilidad aparente de las dietas y características fisicoquímicas de las heces. Observamos distintos valores en los coeficientes de digestibilidad de nutrientes (Tabla 4) al compararlos con otros estudios (5-7), que pudieron verse afectados por factores como: la relación forraje:concentrado, la composición de los ingredientes de la dieta y la cantidad de alimento suministrado.}

La cantidad total de MS suministrada a cada animal en este experimento fue el equivalente al $2 \%$ del peso corporal, incluyendo como mínimo el $1 \%$ del peso corporal del animal como forraje (heno Cross Coast), conforme a las recomendaciones del Consejo Nacional de Investigación (14). La relación forraje:concentrado fue de 60:40, con base en el suministro de energía, lo cual representa una relación de MS de 75:25. Miraglia et al (6) analizó la digestibilidad de distintas proporciones de forraje:concentrado y observó que a medida que aumentaba el porcentaje de concentrado, los coeficientes de digestibilidad de MS, materia orgánica, EB y PC también aumentaron. Cuando dichos autores utilizaron una relación de 75:25 en la dieta, al igual que lo hicimos nosotros, éstos 
coefficients of the DM, organic matter, GE and $\mathrm{CP}$ also increased. When these authors used a 75:25 diet ratio, as we did, they observed similar apparent digestibility values. The differences between the results can be attributed to different qualities of forage used in the studies. Manzano et al (5) provided food with forage:concentrate ratio of 40:60 ad libitum and observed higher nutrient digestibility coefficients than we did.

Miraglia et al (6) note that when a diet comprised of concentrate and lower quality forage favors nutrient digestibility.

The forage used in the present study had a chemical composition similar to that the Bermuda Grass hay recommended by NRC (14) and superior to the hay used by Miraglia et al (6). The hay used in our study is considered a good quality hay for horses, and accounted for a greater proportion of the total diet, which may have contributed to the consistency of the digestibility coefficients.

The amount of citrus pulp added to the concentrate did not affect the digestibility of the fiber fraction. These results are consistent with a study by Oliveira et al (2), in which pectin was added to horse diets. According to the authors, the rapid rate of food passage in horses may not have allowed sufficient microorganism activity to degrade the fiber, which resulted in no change in the digestibility of NDF and ADF. A similar observation was made by Weyenberg et al (21), who noted that the higher forage:concentrate ratio in the diet, the faster the rate of passage through the entire gastrointestinal tract.

According to Miraglia et al (6), the digestibility of the fiber fraction decreases with the addition of concentrate to the diet. We observed no decrease in fiber digestibility in this study, most likely due to the low percentage of concentrate in the diet and the quality of the hay, which provided a substrate for microorganism activity in the large intestine of horses.

We observed a GE digestibility coefficient of $46.15 \%$, which is close to that found in diets composed solely of forage (7). This coefficient is lower than that observed by Ott et al (4) and Manzano et al (5), which could be explained by the higher amount of concentrate provided in the earlier studies.

Although the GE digestibility coefficient we observed was lower than that reported in other studies using citrus pulp (5-6), the values did not differ depending on the levels of citrus pulp included (Table 4), indicating that the observaron valores de digestibilidad aparente similares. Las diferencias entre los resultados se pueden atribuir a las distintas calidades de forraje utilizadas en los estudios. Manzano et al (5) suministró alimentos una relación forraje:concentrado de 40:60 ad libitum y observó coeficientes de digestibilidad de nutrientes más altos que los que observamos nosotros.

Miraglia et al (6) observó que una dieta compuesta por concentrado y un forraje de menor calidad favorece la digestibilidad de nutrientes.

El forraje utilizado en el presente estudio tenía una composición química similar a aquella del heno Bermuda Grass recomendado por el Consejo Nacional de Investigación (14) y superior al heno utilizado por Miraglia et al (6). El heno utilizado en nuestro estudio se considera heno de buena calidad para el consumo de caballos y representó una proporción mayor en la dieta total, lo cual pudo haber contribuido a la consistencia en los coeficientes de digestibilidad.

La cantidad de pulpa de cítricos que se añadió al concentrado no afectó la digestibilidad de la fracción de fibra. Estos resultados son consistentes con el estudio de Oliveira et al (2), en el cual se añadió pectina a las dietas de los caballos. Según los autores, la rápida tasa de paso del alimento en lo caballos puede no haber permitido que hubiera la suficiente actividad de microorganismos como para degradar la fibra, lo cual resultó en que no hubiera ningún cambio en la digestibilidad de FDA y FDN. Weyenberg et al (21) hizo una observación similar al afirmar que entre mayor proporción forraje:concentrado en la dieta, más rápido sería el paso del alimento por el tracto gastrointestinal. Según Miraglia et al (6), la digestibilidad de la fracción de fibra disminuye al añadir concentrado a la dieta. En este estudio no observamos disminución alguna en la digestibilidad de fibra, probablemente debido al bajo porcentaje de concentrado en la dieta y a la calidad del heno, el cual proporcionó un sustrato para la actividad de microorganismos en el intestino grueso de los caballos.

Observamos un coeficiente de digestibilidad de EB de $46.15 \%$, el cual se aproxima al porcentaje encontrado en dietas compuestas únicamente de forraje. Este coeficiente es menor al observado por Ott et al (4) y Manzano et al (5), lo cual podría explicarse por una mayor cantidad de concentrado que fue suministrada en los estudios anteriores. Aunque el coeficiente de digestibilidad de EB que observamos fue menor a aquel reportado en otros estudios que utilizaron pulpa de cítricos (5-6), no hubo diferencia en los valores de acuerdo a los niveles de pulpa de cítricos incluidos (Tabla 4), lo cual indica que la inclusión de este ingrediente no 
inclusion of this ingredient did not negatively alter the digestibility of GE. The consistent GE digestibility coefficients can also be explained by the consistent levels of NDF and ADF digestibility (2), which provided a constant substrate for degradation by microorganisms, which produces energy.

Adding fiber to the diet increases intestinal motility, which may impair the digestibility of nutrients in the small intestine. This could explain the low value of the GE digestibility observed in this study.

The presence of fiber as well as the quality and quantity of food intake, particle size and speed of transit of the digesta can affect both nutrient digestibility and feces quality in horses (21). Studying nutrient digestibility in conjunction with the physicochemical characteristics of feces is important for evaluating digestive tract function, as it allows the diagnosis of gastrointestinal disorders.

We observed no effect ( $p>0.05$ ) of diet on the color of the feces, which had a greenish color. Feces color is primarily influenced by the forage used (22), and the color observed in this study was due to the characteristics and the amount of the hay provided ( $75 \%$ Coast Cross hay on a DM basis).

The consistency of the feces observed in this study was normal, suggesting that adding citrus pulp to the diet does not promote production of high levels of lactic acid and consequently feces fluidization, which can be proven by maintaining the $\mathrm{pH}$ and buffering capacity (Table 5).

The fecal $\mathrm{pH}$ was not influenced $(\mathrm{p}>0.05)$ by treatment (Table 5). The mean $\mathrm{pH}$ value we observed (6.62) is considered appropriate for the activity of cellulolytic bacteria that ferment cell wall carbohydrates, thereby producing short chain fatty acids (SCFA) that are absorbed in the large intestine $(23,24)$.

The buffering capacity conferred the feces, may be related to ion exchange at the SCFA absorption time, which occurs through the absorption of sodium ions $\left(\mathrm{Na}^{+}\right)$at the apical membrane of the absorptive cells in exchange with hydrogen ions $\left(\mathrm{H}^{+}\right)$, this process can be directly linked to the exchange of chlorine $(\mathrm{Cl})$ and bicarbonate $\left(\mathrm{HCO}_{3}\right)(21)$, process according to Van Soest et al (15), is essential for maintaining proper $\mathrm{pH}$ levels, as evidenced in this study. alteró de forma negativa la digestibilidad de EB. La consistencia de los coeficientes de digestibilidad de EB también se puede explicar por los niveles consistentes de digestibilidad de FDA y FDN, que proporcionaron un sustrato para la degradación por parte de microorganismos, lo cual produce energía.

Añadir fibra a la dieta aumenta la motilidad intestinal, lo cual puede afectar la digestibilidad de los nutrientes en el intestino delgado. Esto podría explicar los bajos valores de digestibilidad de EB observados es este estudio.

La presencia de fibra, al igual que la cantidad y la calidad de la ingesta de alimentos, el tamaño de las partículas y la velocidad del tránsito de la digesta pueden afectar tanto la digestibilidad de nutrientes como la calidad de las heces en caballos (21). Estudiar la digestibilidad de nutrientes conjuntamente con las características fisicoquímicas de las heces resulta importante para evaluar la función del aparato digestivo, ya que permite diagnosticar trastornos gastrointestinales. No observamos que la dieta tuviera efecto alguno $(p>0.05)$ en el color de las heces, que fueron de color verdoso. El color de las heces está influenciado principalmente por el tipo de forraje utilizado (22), y el color observado en este estudio se dio por las características y la cantidad del heno que fue suministrado $(75 \%$ de heno Coast Cross a base de MS).

En este estudio se observó que la consistencia de las heces fue normal, lo cual indica que agregar pulpa de cítricos a la dieta no propicia la producción de altos niveles de ácido láctico y por ello la fluidización de las heces, lo cual se puede demostrar ya que se mantiene el pH y la capacidad tampón (Tabla 5).

El tratamiento no tuvo influencia $(p>0.05)$ sobre el $\mathrm{pH}$ fecal (Tabla 5). El valor medio de $\mathrm{pH}$ que observamos (6.62) se considera apropiado para la actividad de bacterias celulolíticas que fermentan los carbohidratos de la pared celular, produciendo así ácidos grasos de cadena corta (AGCC) que son absorbidos en el intestino grueso $(23,24)$.

La capacidad tampón hallada en las heces puede estar relacionada al intercambio de iones en el tiempo de absorción de los AGCC, que ocurre por mediante la absorción de iones de sodio $\left(\mathrm{Na}^{+}\right)$en la membrana apical de las células absortivas en el intercambio de iones hidrógeno $\left(\mathrm{H}^{+}\right)$, este proceso puede estar ligado directamente al proceso de intercambio de cloro $(\mathrm{Cl})$ y bicarbonato $\left(\mathrm{HCO}_{3}\right)$ (21), proceso que según Van Soest (15) es esencial para mantener niveles de $\mathrm{pH}$ adecuados, según lo confirma este estudio. 
The forage:concentrate ratio $(75: 25$, based on DM) may have created favorable conditions in the large intestine for cellulolytic bacteria, data that corroborate with Hoffman (25) findings, which cites that diets with higher amounts of roughage, the main SCFA produced is the acetate.

This indicates that the main substrates for fermentation in large intestine were rapidly and slowly fermentable carbohydrate, with predominance production of weak acids.

The quantity and the quality of fiber in the diet may modify intestinal transit, leading to changes in fecal characteristics. The treatment tested in this present study provided a high amount of fiber as a substrate for the microorganisms. The fiber also has high $B C$ due to the exchange of cations and metallic ions (16). Consistent with this concept, we observed no reduction in BC in this study (Table 5), this demonstrates that animals fed diets with increasing levels of citrus pulp -an ingredient that is considered a "super fiber"- maintained a fecal pH of above 6.0, which is optimal for fermentation by cellulolytic bacteria.

In conclusion horses can identify the presence of citrus pulp in concentrate and prefer concentrates without citrus pulp.

Adding up to $28 \%$ citrus pulp to horse diets does not negatively affect the digestibility of nutrients and the physicochemical characteristics of the feces; thus, it is an alternative energy ingredient in the formulation of horse diets.
La proporción forraje:concentrado (75:25, con base en MS) puede haber propiciado condiciones favorables para las bacterias celulolíticas en el intestino grueso, datos corroborados por los hallazgos de Hoffman (25), quien cita que en las dietas con mayores cantidades de forraje, el principal AGCC producido es el acetato.

Lo anterior indica que los principales sustratos para la fermentación en el intestino grueso fueron carbohidratos fermentables rápida y lentamente, con un predominio en la producción de ácidos débiles.

La cantidad y la calidad de fibra en la dieta pueden modificar el tránsito intestinal, lo cual lleva a cambios en las características fecales. El tratamiento sometido a prueba en este estudio brindo una alta cantidad de fibra como sustrato para los microorganismos. La fibra también una alta CT debido al intercambio de cationes e iones metálicos (16). De manera consistente con este concepto, no observamos una reducción de CT en este estudio (Tabla 5), lo cual demuestra que los animales alimentados con dietas con un contenido cada vez mayor de pulpa de cítricos -ingrediente que se considera una "supefibra"- mantuvieron un pH superior a 6.0, nivel óptimo para la fermentación por parte de las bacterias celulolíticas.

En conclusión, los caballos pueden identificar la presencia de pulpa de cítricos en el concentrado y prefieren los concentrados que no contienen pulpa de cítricos.

Agregar un $28 \%$ de pulpa de cítricos a las dietas de los caballos no afecta de forma negativa la digestibilidad de los nutrientes ni las características fisicoquímicas de las heces, y por lo tanto es una alternativa de ingrediente energético en la formulación de dietas para caballos.

\section{REFERENCES}

1. Brandi RA, Furtado CA. Nutritional and metabolic importance of fiber in the horse diet. Rev Bras Zootec 2009; 38:246-258.

2. Oliveira GJC, Lima JAF, Araújo KV, Fialho ET, Bertechini AG, Pérez JRO, Freitas RTF. Effect of Pectin and Soybean Meal Addition on the Apparent Digestibility of Nutrients, in Horses. Rev Bras Zootec 2002; 31(3):1184-1192.

3. Furtado CE, Brandi RA, Ribeiro LB. Utilização de coprodutos e demais alimentos alternativos para dietas de equinos. Rev Bras Zootec 2011.; 40:214-223.
4. Ott EA, Feaster JP, Lieb S. Acceptability and digestibility of dried citrus pulp by horses. J Anim Sci Champaign 1979; 49(4):983-987.

5. Manzano A, Freitas AR, Esteves SN, Novaes NJ. Pelleted Citrus Pulp in Equine Feeding. Rev Bras Zootec 1999; 29(6):1327-1332.

6. Miraglia N, Bergero D, Polidori M, Peiretti PG, Ladetto $G$. The effects of a new fibrerich concentrate on the digestibility of horse rations. Livest Sci 2006; 100:10-13. 
7. Peiretti PG, Meineri G, Miraglia N, Mucciarelli M, Bergero D. Intake and apparent digestibility of hay or hay plus concentrate diets determined in horses by the total collection of feces and n-alkanes as internal markers. Livest Sc 2006; 100:189-194.

8. Richards N, Hinch GN, Rowe JB. The effect of current grain feeding practices on hindgut starch fermentation and acidosis in the Australian racing Thoroughbred. Aust Vet J 2006; 84(11): 402-407.

9. Godoi FN, Almeida FQ, Guarienti GA, Santiago JM, Guedes Júnios D, Nogueira YC, Brasileiro LS. Blood profile and characteristics of the feces of horses fed with high fat diets. Cien Rural 2009; 39(9):2571-2577.

10. Berg EL, Fu CF, Potter JH, Kerley MS. Fructooligosaccharide supplementation in the yearling horse: effects on fecal $\mathrm{pH}$, microbial content, and volatile fatty acid concentrations. J Anim Sci 2005; 83(7):1549-1553.

11. Zeyner A, Geibler C, Dittrich A. Effects of hay intake and feeding sequence on variables in faeces and faecal water (dry matter, $\mathrm{pH}$ value, organic acids, ammonia, buffering capacity) of horses. J Anim Physiol Anim Nutr 2004; 88(1):7-19.

12. Moreira CM. Palatabilidade e digestibilidade aparente de dietas com níveis crescentes de inclusão de polpa cítrica para equinos [Dissertação de Mestrado]. Pirassununga. Faculdade de Zootecnia e Engenharia de Alimentos, São Paulo, Brasil. 2014.

13. Statistical Analysis System - SAS. SAS OnlineDoc. Version 9.1.3. Cary: SAS Institute, 2004.

14. NRC. Nutrients requirements of domestic horses. 6.ed. Washington, D.C.: National Academy of Science 2007; 341.

15. AOAC. Official Methods of Analysis. 19. ed. Association of Official Analytical Chemistry, Arlington, VA. 2012.

16. Van Soest PJ, Robertson JP, Lewis BA. Methods for dietary fiber, neutral detergent fiber, and nonstarch polysaccharides in relation to animal nutrition. J Dairy Sci $1991 ; 74: 3583-3597$.
17. Cairns MC, Cooper JJ, Davidson HPB, Mills DS. Association in horses of orosensory characteristics of foods with their postingestive consequences. Animal Science 2002; 75: 257-265.

18. Tribucci AMO, Brandi RA, Balieiro JCC, Titto EAL, Bueno ICS. Palatability of horse diets containing citrus pulp (Citrus sinensis) through the preference test. Ital J Anim Sci 2013; 12(33):204-207.

19. Assis AJ, Campos JMS, Filho SCV, Queiroz AC, Lana RP, Euclydes RF, Neto JM, Magalhães ALR, Mendonça SS. Citrus pulp in diets for milking cows. 1. Intake of nutrients, milk production and composition. Rev. Bras. Zootec 2004; 33(1):242-250.

20. Müller $C E$, Udén P. Preference of horses for grass conserved as hay, haylage or silage. Anim Feed Sci Technol 2007; 132:66-78.

21. Weynberg SV, Sales J, Janssens GPJ. Passage rate of digesta through the equine gastrointestinal tract: A review. Livest Sci 2006; 99:3-12.

22. Gonçalves S, Leblond A, Drogoul C, Julliand V. Using feces characteristics as a criterion for the diagnosis of colic in the horse: a clinical review of 207 cases. Revue de Méd Vét 2006; 1(157) 3-10.

23. Filgueiras JM, Melo UP, Ferreira C, França AS, Shimoda E. Feces characteristics and faecal sand excretion in equine keep at pasture in Cachoeiro Itapemirim city, Espírito Santo, Brazil. Cienc Anim Bras 2009; 10(4):12001206.

24. Brokner C, Austbo D, Naesset JA, Knudsen KEB, Tauson AT. Equine pre-caecal and total tract digestibility of individual carbohydrate fractions and their effect on caecal $\mathrm{pH}$ response. Arch Anim Nutr 2012; 66(6):490-506.

25. Hoffman RM. Carbohydrate metabolism and metabolic disorders in horses. Rev Bras Zootec 2009; 38:270-276. 